\title{
Karakterisasi Kromosom Stroberi (Fragaria vesca L. subsp. californica Cham. \& Schltdl. cv. Californica) Hasil Poliploidisasi
}

\author{
ROSYIDATUL KHOIROH ${ }^{1}$, GANIES RIZA ARISTYA ${ }^{2}$, SUTIKNO $^{3}$, NIKEN SATUTI NUR \\ HANDAYANI $^{2}$ \\ ${ }^{1}$ Alumni Mahasiswa Biologi, Fakultas Biologi, Universitas Gadjah Mada \\ ${ }^{2}$ Laboratorium Genetika, Fakultas Biologi, Universitas Gadjah Mada \\ ${ }^{3}$ Laboratorium Struktur dan Perkembangan Tumbuhan, Fakultas Biologi, Universitas Gadjah Mada \\ Jl. Teknika Selatan, Sekip Utara, Sleman, Yogyakarta 55281 \\ email: ganies_riza@ugm.ac.id
}

\begin{abstract}
Fruit consumption such as strawberries always increase in Indonesia and reaching about 210 tons in 2011. Strawberry (Fragaria vesca L. subsp. californica Cham. and Schltdl. cv. Californica) has been developed in Indonesia, especially in Banyuroto, Sawangan, the district of Magelang, Central Java. In order to improve the fruit productivity (quality and quantity), genetic characterization including chromosomes character of this fruit are needed to be investigated. Therefore, the research was conducted to determine the chromosomes number, chromosomes size, chromosomes shape and karyotype of control and strawberries treated by colchicine as mutagenic agent. The method was squash and flow cytometry method. Whereas the cell suspension sample were observed used flow cytometer instrument. The result of research shown that the chromosome number of strawberry Californica in normal and treatment strawberries was $2 n=14$. The chromosomes shape of normal strawberry was 10 metacentric and 4 submetacentric. Whereas the chromosomes shape of treatment strawberries used colchicine was 10 metacentric and 4 submetacentric. Flow cytometric analysis shown that control strawberries and treated strawberries has diploid ploidy level.
\end{abstract}

Keywords: chromosomes, colchicine, flow cytometry, polyploidization, strawberry Californica

\section{PENDAHULUAN}

Buah stroberi merupakan buah asli Eropa yang saat ini telah mengalami domestikasi di berbagai negara. Di Indonesia, stroberi telah didomestikasi dan dikembangkan di Jawa Timur, Jawa Tengah dan Jawa Barat terutama di daerah-daerah dengan ketinggian lebih dari 1000 mdpl. Dalam satu tahun, buah stroberi dapat bereproduksi hingga lima kali yang puncaknya terjadi pada bulan Juli-Agustus. Usaha perbaikan kualitas buah stroberi telah dilakukan oleh Balai Penelitian Jeruk dan Buah Subtropika (Balitjestro) dengan mengoleksi dan mengevaluasi jenis stroberi di Indonesia, khususnya di Jawa dan Bali untuk mendapatkan varietas terbaik untuk dikembangkan (Hanif dan Ashari, 2013).

Buah stoberi bukan merupakan buah asli Indonesia, kualitas buah yang dihasilkan lebih rendah dibanding dengan buah stroberi yang berasal dari wilayah Eropa, antara lain ukuran buah yang relatif kecil dan rasanya yang sangat masam. Selain itu banyak hama dan penyakit yang menyerang tanaman stroberi Indonesia sehingga menurunkan produksi hingga mencapai $80 \%$. Hal ini disebabkan karena kurangnya ketersediaan bibit yang berkualitas. Penyediaan bibit stroberi yang dilakukan secara konvensional dengan menggunakan stolon yang berasal dari tanaman induk, berpotensi membawa penyakit infeksi patogen dari tanaman induk (Hanif dan Ashari, 2013).

Perbaikan genetik merupakan perbaikan kualitas tanaman, salah satunya melalui manipulasi kromosom. Perbaikan secara genetik dapat menjadi solusi yang baik bagi peningkatan kualitas tanaman stroberi di Indonesia. Selain itu perbaikan ini juga dapat meningkatkan ukuran organ vegetatif dan organ generatif tanaman serta meningkatkan ketahanan tanaman stroberi. Salah satu metode manipulasi kromosom adalah dengan 
poliploidisasi dengan menggunakan mutagen tertentu, misalnya kolkisin (Mukti, 2005).

Poliploidisasi merupakan proses yang umum terjadi pada tumbuhan tingkat tinggi (Wang et al., 2009). Tumbuhan yang mengalami poliploidisasi akan memiliki keuntungan secara fenotipik dan perubahan secara morfologi, fisiologi, dan metabolisme sekunder yang dapat meningkatkan kemampuan tanaman tersebut, misalnya peningkatan resistensi terhadap patogen, waktu pembungaan yang lebih lama, serta organ reproduktif dan vegetatif yang berukuran lebih besar (Aversano et al., 2012). Stroberi sendiri merupakan spesies yang secara natural terdapat sebagai organisme poliploid, mulai dari diploid hingga dekaploid (Hummer et al., 2011).

Studi lebih lanjut yang mempelajari sitogenetika dan perbaikan genetik pada tanaman stoberi di Indonesia belum dipelajari lebih mendalam. Oleh karena itu, tujuan dari penelitian ini adalah untuk mempelajari jumlah, ukuran, bentuk dan karyotype kromosom stroberi kultivar Californica normal dan hasil induksi dengan konsentrasi kolkisin (a) $0,1 \%$ induksi akar 24 jam; (b) $0,1 \%$ induksi daun 24 jam; (c) $0,1 \%$ induksi akar 36 jam dan (d) $0,1 \%$ induksi daun 36 jam pada salah satu stroberi yang telah berkembang di Indonesia, yaitu stroberi kultivar Californica (Fragaria vesca L. subsp. californica Cham. and Schltdl. cv. Californica). Dengan demikian, diharapakan tanaman stroberi dapat berkembang lebih baik sehingga produktivitas buah stroberi meningkat dan dapat digunakan untuk memenuhi kebutuhan stroberi dalam negeri.

\section{METODE}

Pengambilan Sampel. Setiap tanaman stroberi Californica yang diperoleh dari sentra "Inggit Stroberi" Banyuroto, Magelang, Jawa Tengah dipotong ujung akarnya secara langsung dari akar yang terbentuk pada stolon yang menjulur dari induk dan dimasukkan dalam tube 1,5 $\mathrm{ml}$ berisi Asam Asetat Glasial $45 \%$ selama 24 jam dalam suhu $4^{\circ} \mathrm{C}$.

Squashing, Karyotype, dan Idiogram. Metode yang digunakan untuk preparasi kromosom adalah metode squash (Nathewet et al., 2009). Sampel yang telah difiksasi dicuci bersih dengan akuades sebanyak tiga kali. Selanjutnya akar direndam dalam larutan $\mathrm{HCl} 1 \mathrm{~N}$ pada temperatur $55-60^{\circ} \mathrm{C}$ selama $10-$ 11 menit. Setelah itu akar dicuci bersih dengan akuades sebanyak tiga kali. Akar kemudian diwarnai dengan aceto carmin 1\% selama 1,5 jam pada suhu kamar. Akar diambil menggunakan kuas dan diletakkan pada gelas benda dan sisa aceto carmin diserap dengan menggunakan tisu. Bagian ujung akar yang terpulas lebih gelap dipotong sepanjang $\pm 2-3 \mathrm{~mm}$ dan diberi 1 tetes gliserin dan ditutup menggunakan gelas penutup. Akar kemudian dipencet dengan alur dari tengah ke pinggir sampai nampak menyebar dan tipis agar akar menjadi satu lapis sel. Selanjutnya preparat disegel dengan menggunakan kutek dan dilabeli menggunakan pensil dan kertas label.

Preparat tersebut kemudian diamati dibawah mikroskop cahaya di Laboratorium Genetika Fakultas Biologi UGM menggunakan mikroskop Olympus BX41 untuk memastikan adanya fase mitosis. Selanjutnya preparat diamati menggunakan mikroskop cahaya di LPPT UGM dan dilakukan pemotretan dengan kamera Nikon yang terintegrasi dengan komputer dan pengukuran sel dilakukan dengan menggunakan software axiovision LE 4.4.

Berdasarkan gambar yang dihasilkan kemudian diamati dan ditentukan jenis fase mitosis yang tampak. Selanjutnya foto yang menunjukkan fase prometafase yang paling bagus diamati untuk dihitung jumlah kromosomnya. Setelah itu satu persatu kromosom pada gambar tersebut diukur lengan panjang (q) dan lengan pendeknya (p) menggunakan Corel Draw X5, kemudian dipotong sesuai bentuk yang teramati dengan menggunakan aplikasi Paint dan Microsoft Excel 2007.

Flow Cytometry. Metode flow cytometry berdasarkan Dooghe et al., (2009) yang merujuk pada Otto (1990) dan Galbraith, (1983) dengan modifikasi. Langkah pertama, jaringan daun segar dipotong menggunakan pisau yang tajam dalam $2000 \mu \mathrm{l}$ buffer Otto I 
(0,1 $\mathrm{M}$ asam sitrat monohidrat dan $0,5 \%$ Tween-20). Selanjutnya sampel disaring menggunakan saringan pore $100 \mu \mathrm{m}$, diambil sebanyak $1000 \mu \mathrm{m}$ dan dimasukkan dalam tube. Larutan tersebut disentrifugasi $1500 \mathrm{rpm}$ 10 menit, supernatan dibuang. Setelah itu larutan ditambah $900 \mu \mathrm{m}$ buffer Otto II $(0,4$ $\left.\mathrm{M} \mathrm{Na} \mathrm{HPO}_{4} \cdot 12 \mathrm{H}_{2} \mathrm{O}\right)$. Selanjutnya sampel disentrifugasi 1500 rpm 10 menit, kemudian supernatan dibuang. Larutan ditambahkan 500 $\mu \mathrm{m}$ pewarna PI. Kemudian dianalisis menggunakan bantuan alat flow cytometer.
Hasil penelitian menunjukkan bahwa jumlah kromosom pada stroberi Californica kontrol dan yang telah diinduksi menggunakan kolkisin pada semua perlakuan menunjukkan hasil yang sama, yaitu $2 n=14$ (Gambar 1\&2). Pengukuran karyotype menunjukkan bahwa karyotype kromosom stroberi Californica kontrol dan perlakuan memiliki bentuk kromosom yang sama. Pada formula karyotype kontrol dan stroberi hasil induksi menunjukkan bahwa kromosom memiliki bentuk metasentris dan submetasentris, yaitu 10m+4sm (Gambar 3).

\section{HASIL}

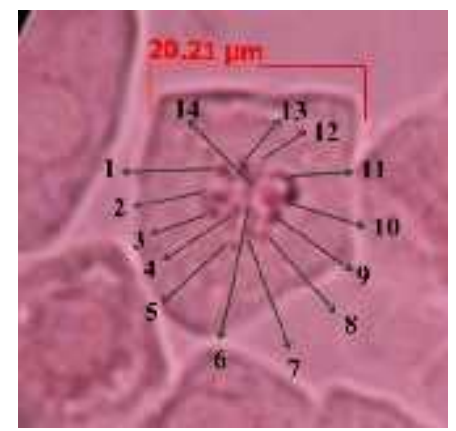

Gambar 1. Jumlah kromosom stroberi Californica kontrol $(2 \mathrm{n}=14)$
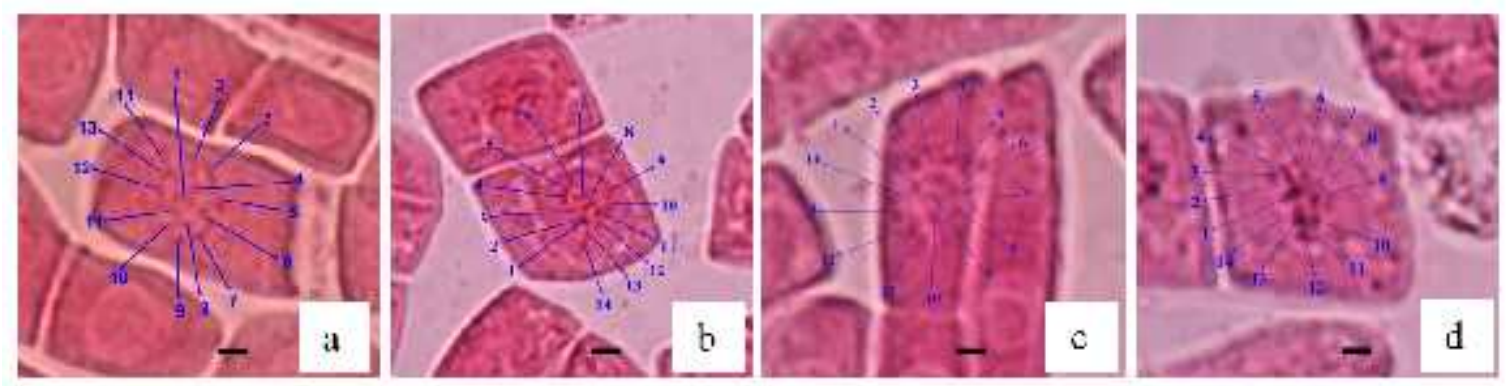

Gambar 2. Jumlah kromosom stroberi Californica induksi kolkisin, yaitu: a. 0,1\% 24 jam induksi Daun; b. 0,1\% 24 jam induksi Akar; c. 0,1\% 36 jam induksi Daun; d. 0,1\% 36 jam induksi Akar. 2n=14. Bar $=5 \mu \mathrm{m}$

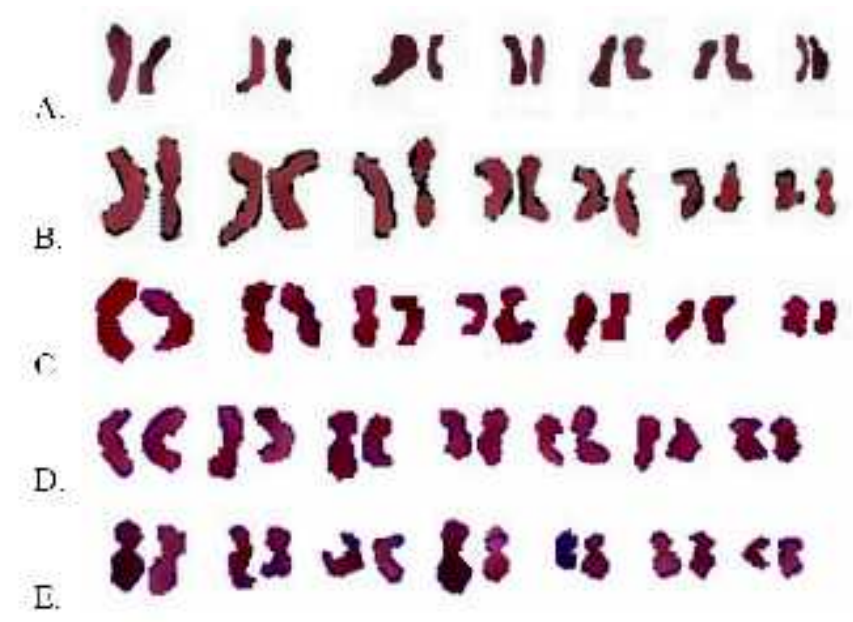

Gambar 3. Karyotype kromosom stroberi Californica: A. kontrol; B. 0,1\% 24 jam induksi daun; C. $0,1 \% 24$ jam induksi akar; D. 0,1\% 36 jam induksi daun; dan E. 0,1\% 36 jam induksi akar. 


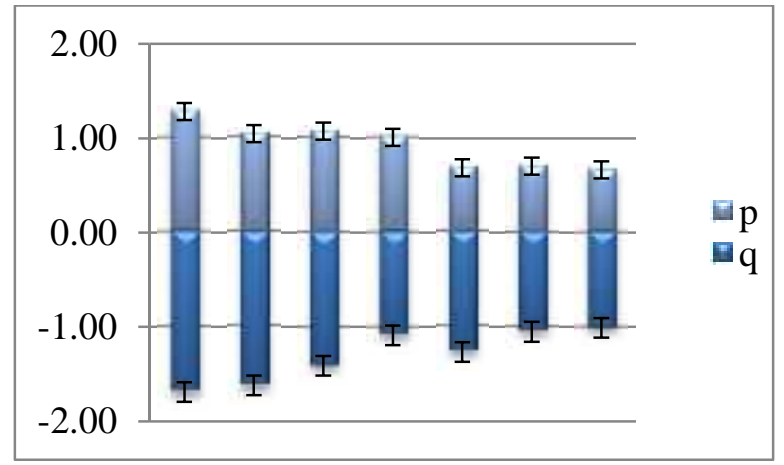

Gambar 4. Idiogram kromosom stroberi Californica kontrol

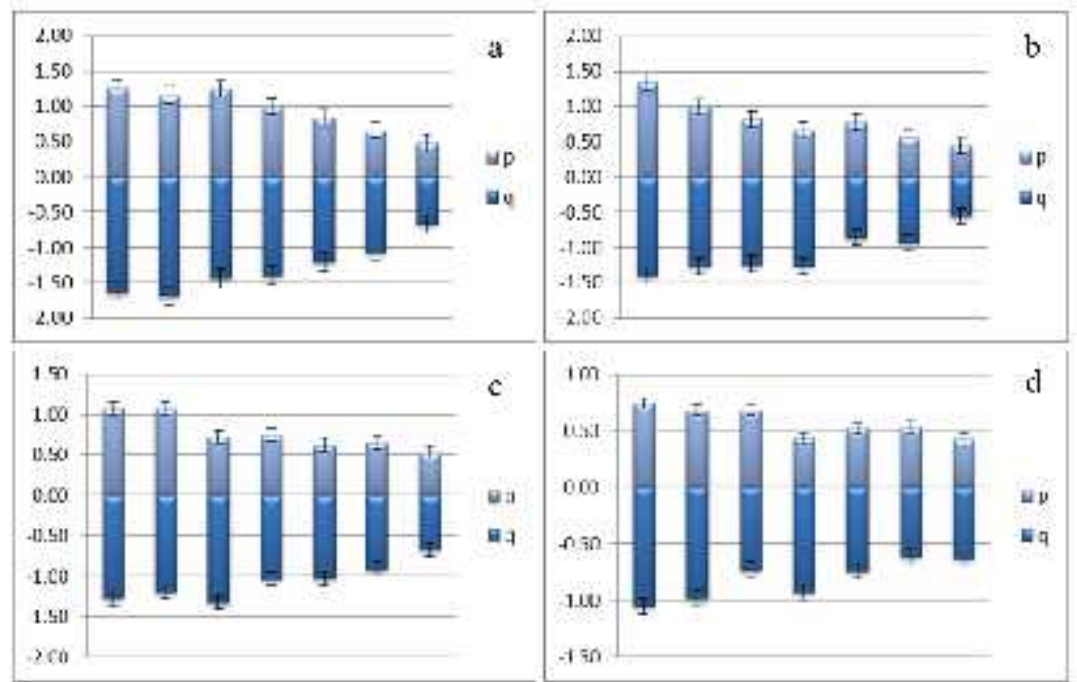

Gambar 5. Idiogram kromosom stroberi Californica induksi (a) 0,1\% 24 jam induksi daun; (b) $0,1 \% 24$ jam induksi akar; (c) $0,1 \% 36$ jam induksi daun; (d) 0,1\% 36 jam induksi akar.

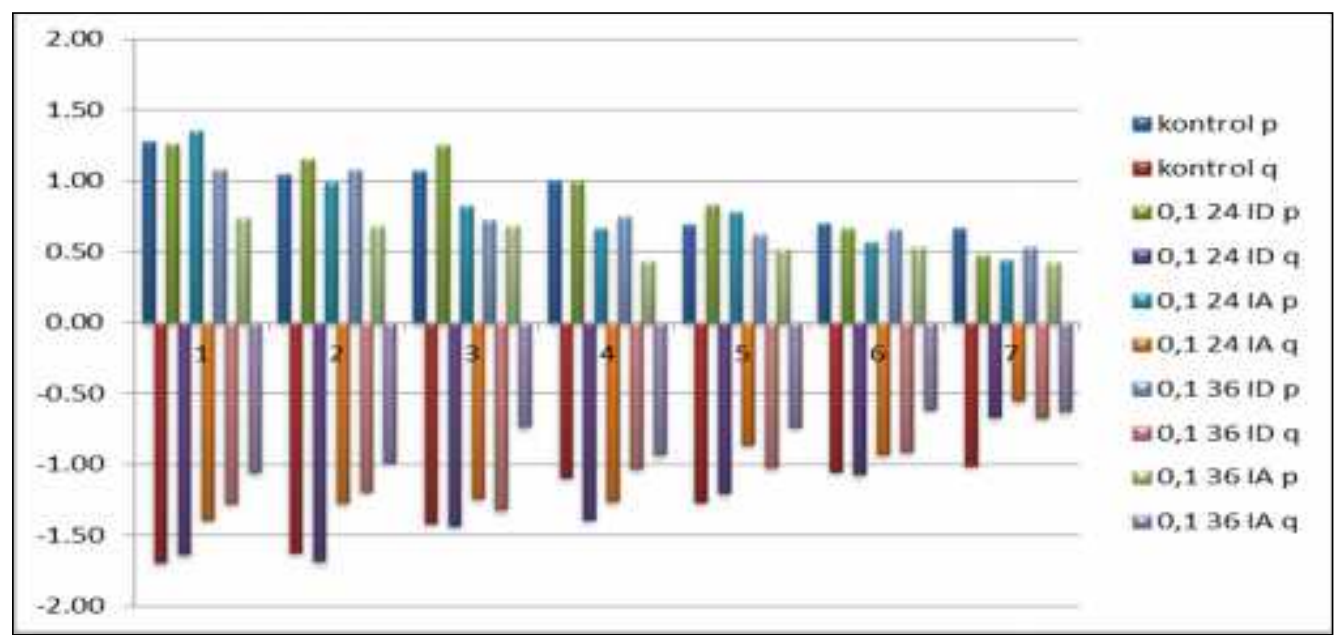

Gambar 6. Perbandingan idiogram kromosom stroberi Californica kontrol dan induksi

Berdasarkan penelitian yang telah dilakukan juga didapatkan hasil dalam bentuk idiogram untuk mengetahui perbedaan panjang relatif kromosom. Hasil idiogram yang diperoleh menunjukkan adanya perbedaan pada panjang relatif kromosom stroberi kontrol dan perlakuan, baik pada lengan pendek (p) maupun pada lengan panjang (q). Idiogram kontrol (Gambar 4) menunjukkan pasangan kromosom yang lebih panjang dibandingkan perlakuan (Gambar 5). Pada kontrol, panjang relatif kromosom lebih 
besar jika dibandingkan dengan semua perlakuan, yaitu berkisar antara 1,60-2,97 $\mu \mathrm{m}$. Pada perlakuan induksi kolkisin konsentrasi $0,1 \% 24$ jam induksi daun dan $0,1 \% 24$ jam induksi akar berturut-turut diperoleh panjang relatif kromosom antara 1,14-2,89 $\mu \mathrm{m}$ dan 1,00-2,74 $\mu \mathrm{m}$. Pada perlakuan 0,1\% 36 jam induksi daun dan $0,1 \% 36$ jam induksi akar masing-masing diperoleh kisaran panjang relatif kromosom antara 1,20-2,35 $\mu \mathrm{m}$ dan 1,05-1,79 $\mu \mathrm{m}$.

Pada Gambar 6, lengan pendek kromosom yang paling panjang dibandingkan dengan perlakuan dimiliki oleh perlakuan $0,1 \% 24$ jam induksi akar, pada pasangan kromosom yang pertama, yaitu $1,35 \mu \mathrm{m}$. Lengan panjang kromosom yang paling panjang dibandingkan kontrol adalah 0,1\% 24 jam induksi daun. Panjang lengan panjang kromosom perlakuan $0,1 \% 24$ jam induksi akar lebih panjang jika dibandingkan perlakuan lain dan kontrol, yaitu 1,63 $\mu \mathrm{m}$.
Pada pasangan kromosom yang kedua, perlakuan $0,1 \% \quad 24$ jam induksi daun menunjukkan hasil paling tinggi, baik pada lengan pendek $(1,16 \mu \mathrm{m})$ maupun lengan panjang $(1,68 \mu \mathrm{m})$. Hal ini juga terjadi pada pasangan kromosom ketiga, yaitu $\mathrm{p}=1,25 \mu \mathrm{m}$ dan $\mathrm{q}=1,43 \mu \mathrm{m}$ dan kromosom keempat, yaitu $\mathrm{p}=1.00 \mu \mathrm{m}$ dan $\mathrm{q}=1,39 \mu \mathrm{m}$.

Pada pasangan kromosom kelima, lengan pendek dan lengan panjang paling panjang berturut-turut adalah perlakuan $0,1 \% 24$ jam induksi daun $(0,84 \mu \mathrm{m})$ dan kontrol $(1,26$ $\mu \mathrm{m})$. Pada pasangan kromosom keenam, lengan pendek dan lengan panjang paling panjang berturut-turut adalah kontrol $(0,70$ $\mu \mathrm{m})$ dan perlakuan $0,1 \% 24$ jam induksi daun $(1,07 \mu \mathrm{m})$. Pada pasangan kromosom ketujuh, lengan pendek dan lengan panjang paling panjang adalah kontrol $(\mathrm{p}=0,66 \mu \mathrm{m}$ dan $\mathrm{q}=1,01 \mu \mathrm{m})$.

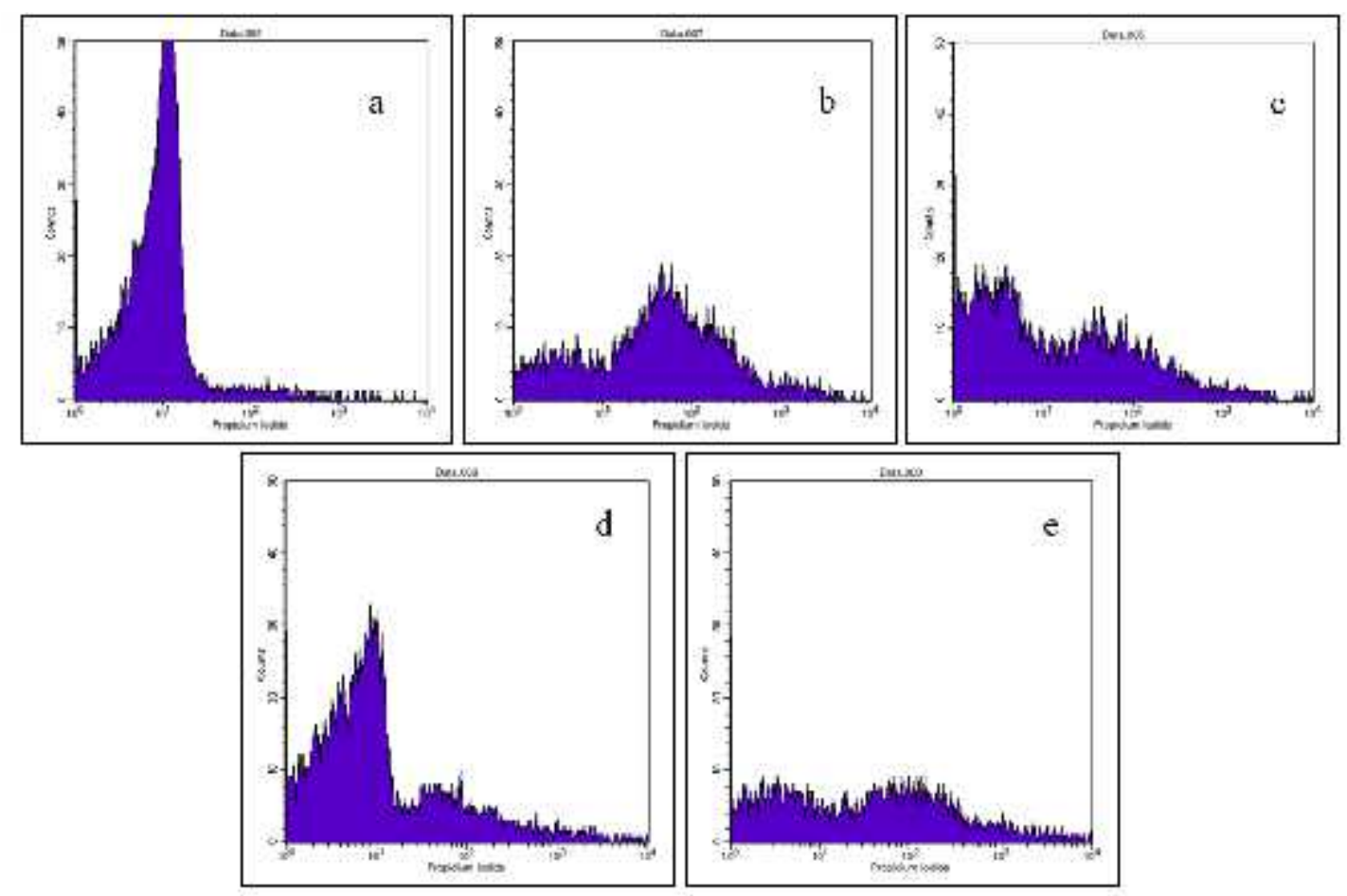

Gambar 7. Peak flow cytometry stroberi Californica hasil induksi kolkisin, yaitu: a. $0,1 \% 24$ jam induksi Daun; b. 0,1\% 24 jam induksi Akar; c. 0,1\% 36 jam induksi Daun; d. 0,1\% 36 jam induksi Akar.

Adapun jumlah ploidi yang ditunjukkan pada Gambar 7 adalah diploid, karena peak yang terbentuk berada pada intensitas yang sama dengan peak stroberi Californica 
kontrol. Berdasarkan pengamatan, didapatkan hasil bahwa kenampakan morfologi menunjukkan perbedaan yang kurang jelas pada daun dan buah stroberi kontrol dan stroberi perlakuan. Perbedaan dapat diamati dari morfologi bunga. Daun dan buah memiliki ukuran yang hampir sama besar antara stroberi kontrol dan stroberi perlakuan (Gambar 8 dan 9).
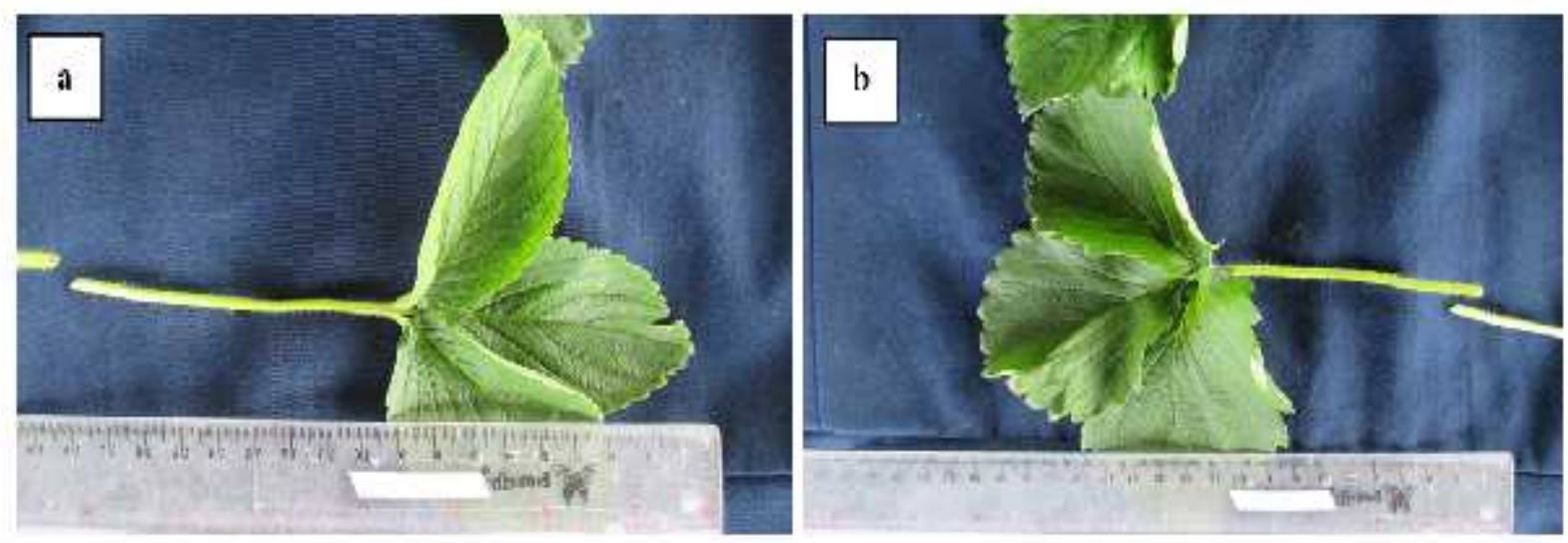

Gambar 8. Morfologi daun stroberi Californica hasil induksi menggunakan kolkisin, yaitu: a. kontrol; b. $0,1 \% 24$ jam induksi daun

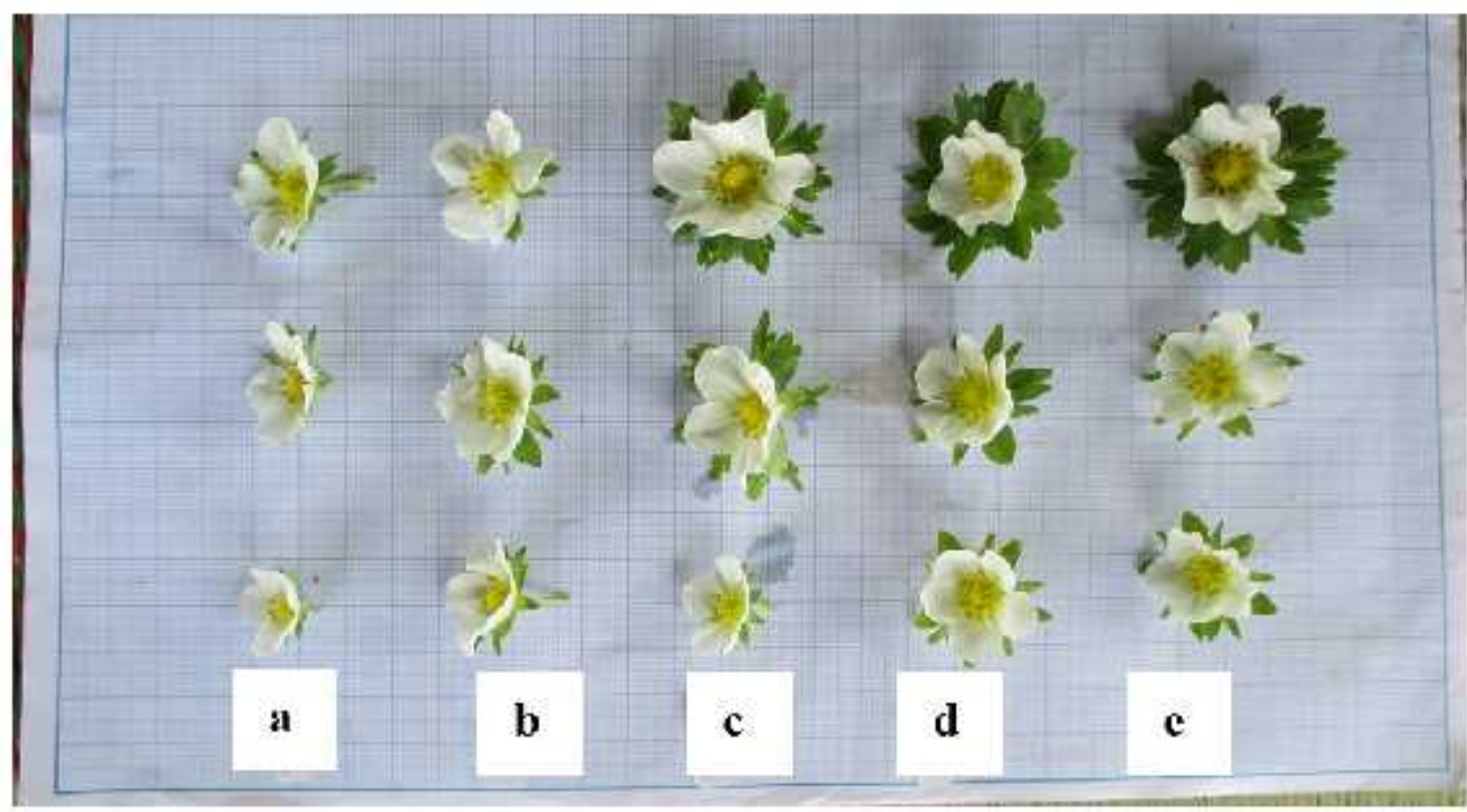

Gambar 9. Morfologi bunga stroberi Californica hasil induksi menggunakan kolkisin, yaitu: a. kontrol; b. 0,1\% 24 jam induksi Daun; c. 0,1\% 24 jam induksi Akar; d. 0,1\% 36 jam induksi Daun; e. 0,1\% 36 jam induksi akar. 


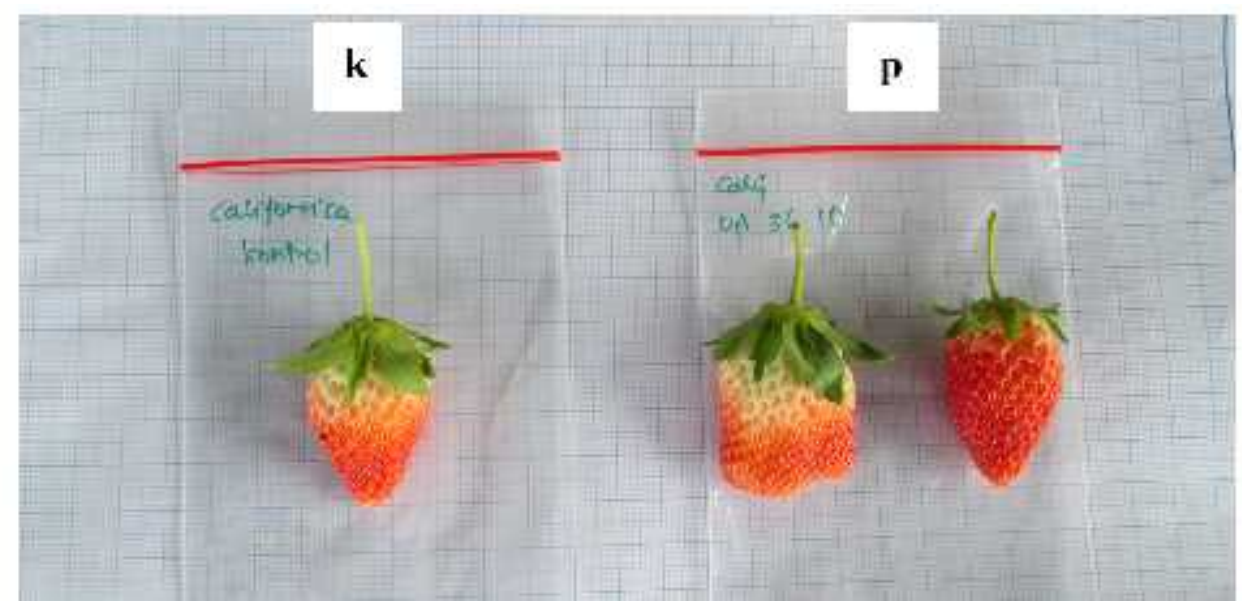

Gambar 10. Morfologi buah stroberi Californica hasil induksi menggunakan kolkisin 0,1\% 36 jam induksi daun (k=kontrol; $\mathrm{p}=$ perlakuan).

Variasi fenotip akibat perlakuan induksi kolkisin juga dapat diamati dari pengambilan data sekunder untuk uji nutrisi. Pada uji nutrisi stroberi Californica didapatkan bahwa kandungan gula total kontrol sebesar 5,26\%. Sedangkan kandungan gula total stroberi Californica hasil induksi pada $0,1 \% 24$ jam induksi daun sebesar 4,16\%, pada $0,1 \% 24$ jam induksi akar sebesar $4,56 \%$, pada $0,1 \%$ 36 jam induksi daun sebesar $4,27 \%$, dan pada $0,1 \% 36$ jam induksi akar sebesar 3,91\%.

Selanjutnya pada uji kandungan asam, stroberi kontrol menunjukkan nilai sebesar $1,07 \%$. Sedangkan kandungan asam stroberi Californica hasil induksi pada $0,1 \% 24$ jam induksi daun sebesar $0,92 \%$, pada $0,1 \% 24$ jam induksi akar sebesar $0,96 \%$, pada $0,1 \%$ 36 jam induksi daun sebesar $0,96 \%$, dan pada $0,1 \% 36$ jam induksi akar sebesar $0,92 \%$.

Selanjutnya pada uji kandungan vitamin $\mathrm{C}$, stroberi kontrol menunjukkan nilai sebesar $64,69 \mathrm{mg} / 100 \mathrm{~g}$. Sedangkan kandungan asam stroberi Californica hasil induksi pada $0,1 \%$ 24 jam induksi daun sebesar $55,21 \mathrm{mg} / 100 \mathrm{~g}$, pada $0,1 \% \quad 24$ jam induksi akar sebesar $56,82 \mathrm{mg} / 100 \mathrm{~g}$, pada $0,1 \% 36$ jam induksi daun sebesar $53,36 \mathrm{mg} / 100 \mathrm{~g}$, dan pada $0,1 \%$ 36 jam induksi akar sebesar $60,94 \mathrm{mg} / 100 \mathrm{~g}$.

Selanjutnya pada uji kandungan vitamin A, stroberi kontrol menunjukkan nilai sebesar $389,49 \mu \mathrm{g} / 100 \mathrm{~g}$. Sedangkan kandungan asam stroberi Californica hasil induksi pada $0,1 \%$ 24 jam induksi daun sebesar $241,43 \mu \mathrm{g} / 100 \mathrm{~g}$, pada $0,1 \% 24$ jam induksi akar sebesar $291,72 \mu \mathrm{g} / 100 \mathrm{~g}$, pada $0,1 \% 36$ jam induksi daun sebesar $274,25 \mu \mathrm{g} / 100 \mathrm{~g}$, dan pada $0,1 \%$ 36 jam induksi akar sebesar $310,88 \mu \mathrm{g} / 100 \mathrm{~g}$.

Secara umum, stroberi kontrol memiliki kandungan nutrisi yang lebih besar dibandingkan perlakuan. Hal ini diduga karena induksi kolkisin menyebabkan buah stroberi lebih tahan terhadap proses pematangan, sehingga kandungan nutrisinya lebih rendah dibandingkan kontrol. Selain itu, perbedaan ini dimungkinkan karena adaptasi stroberi dari lingkungan lama (Banyuroto, Magelang) menuju lingkungan yang baru (Yogyakarta) yang memiliki perbedaan parameter lingkungan, misalnya temperatur, ketinggian tempat, dan kelembaban udara. Sehingga, dimungkinkan stroberi terpengaruh oleh kondisi lingkungan tersebut dan menyebabkan perubahan dalam kandungan stroberi.

\section{PEMBAHASAN}

Kolkisin $\left(\mathrm{C}_{22} \mathrm{H}_{25} \mathrm{O}_{6} \mathrm{~N}\right)$ merupakan suatu alkaloid yang berasal dari umbi dan biji tanaman Colchicum autumnale Linn. yang termasuk dalam familia Liliaceae. Senyawa ini bersifat sebagai racun, terutama terhadap nukleus yang sedang membelah dan menyebabkan penggandaan kromosom tanpa pembentukan dinding sel (Suryo, 2007). Induksi kolkisin akan membuat protein tubulin yang merupakan komponen molekular 
pembentuk mikrotubul berikatan dengan kolkisin. Hal ini menyebabkan mikrotubul tidak terbentuk dan migrasi ke arah kutub yang benar menjadi terganggu (Dhooge et al., 2009). Selain itu mikrotubul juga betugas untuk membentuk dinding sel setelah pembelahan kromosom. Namun apabila mikrotubul tidak terbentuk, maka dinding sel baru tidak terbentuk. Dengan demikian sel akan mengandung jumlah kromosom lipat dua karena pemisahan kromosom pada anafase tidak terjadi dan kromosomkromosom berserakan dalam sitoplasma (Suryo, 2007). Pada stroberi Californica jumlah kromosom hasil induksi tetap sama dengan kontrol, yaitu $2 n=14$. Hal ini mungkin disebabkan karena penelitian ini dilakukan selang satu tahun setelah waktu induksi sehingga dimungkinkan daya kolkisin telah habis (Suryo, 2007). Oleh karena itu tanaman yang semula telah terpolipolidisasi dimungkinkan jumlah kromosomnya kembali pada kondisi awalnya untuk menstabilkan diri, yaitu $2 n=14$.

Perbedaan panjang antara lengan pendek dan lengan panjang kontrol dan perlakuan mungkin disebabkan oleh kondensasi kromosom dalam sel yang berbeda-beda, sehingga hasil pengukuran juga berbeda-beda. Hal ini diduga karena selain membuat kromosom terduplikasi, kolkisin juga memberikan efek kondensasi pada kromosom.

Analisis flow cytometry melibatkan tiga komponen yang meliputi komponen fluidik sebagai sumber sel, komponen optik berupa dichroic mirrors untuk filtrasi pancaran epifloresen, dan komponen elektronik untuk mengubah sinyal cahaya menjadi data digital. Untuk mendapatkan data flow cytometry dilakukan dengan mengkonversi sinyal cahaya yang dihasilkan dari pendaran dalam suspensi menjadi getaran elektronik yang dikonversi lagi menjadi channel number, dan kemudian data yang diperoleh disimpan dalam sistem komputer (BD Biosciences, 2000).

Hasil analisis flow cytometry menunjukkan bahwa tanaman stroberi hasil induksi memiliki derajat ploidi diploid. Hal ini terjadi karena pemberian atau induksi kolkisin dilakukan ketika sel masih mengalami fase mitosis aktif yang ketika itu ada sebagian sel yang mengalami fase-fase tertentu sebelum terkena pengaruh kolkisin, sehingga masih ada sel-sel yang bersifat diploid (Arisuryanti, 1994).

Selain itu, terjadinya perbedaan hasil analisis flow cytometry terhadap satu spesies tumbuhan yang sama pernah terjadi hingga $300 \%$. Hal ini mungkin disebabkan oleh stadium perkembangan dan status fisiologi organ, jaringan, atau sel yang dianalisis yang berubah secara radikal. Adanya stress, perbedaan ekotipe, dan genotip akan menimbulkan perbedaan kandungan DNA relatif, sehingga hasil pengukuran juga berbeda. Hal lain yang dapat menimbulkan perbedaan terhadap hasil analisis adalah pengaturan instrumen yang berbeda pada laboratorium yang satu dan lainnya (Ochatt, 2008).

\section{KESIMPULAN}

Kromosom stroberi kultivar Californica normal dan induksi memiliki jumlah kromosom $2 \mathrm{n}=14$, formula karyotype $10 \mathrm{~m}+4 \mathrm{sm}$, dengan ukuran kromosom yang berkisar antara 1,55-3,25 $\mu \mathrm{m}$ (kontrol), dan $1,10-2,92 \mu \mathrm{m}$ dan $(0,1 \% 24$ jam induksi akar), $0,89-2,82 \mu \mathrm{m}(0,1 \% 24$ jam induksi daun $)$, $1,10-2,37 \mu \mathrm{m}(0,1 \% 36$ jam induksi akar) dan $1,01-1,80 \mu \mathrm{m}(0,1 \% 36$ jam induksi daun). Idiogram terdiri atas tujuh pasang kromosom. Analisis flow cytometry menunjukkan bahwa stroberi kultivar Californica kontrol dan induksi memiliki jumlah ploidi diploid.

\section{UCAPAN TERIMA KASIH}

Ucapan terima kasih diberikan kepada Program Grant Hibah Kompetensi Tahun Anggaran 2015 No. 179/LPPM/2015 dan Hibah BOPTN Fakultas Biologi UGM Tahun Anggaran 2014 No. UGM/BI/1882/M/05/01.

\section{DAFTAR PUSTAKA}

Arisuryanti T. 1994. Pengaruh Kolkhisin terhadap Pembelahan Mitosis Tanaman Nilam (Pogostemon cablin Benth.). Yogyakarta: Laporan Penelitian OPF Fakultas Biologi UGM. 
Aversano R, Ercolano MR, Caruso I, Fasano C, Rosellini D, Carputo D. 2012. Molecular Tools for Exploring Polyploid Genomes in Plants. International Journal of Molecular Science. vol (13):10316.

Biosciences BD. 2000. Introduction to Flow Cytometry: a Learning Guide. USA: Becton, Dickinson and Company.

Dhooge E, Grunewald W, Leus L, Labeke MV. 2009. In vitro polypliodisation of Helleborus species. Euphytica. vol 165:89-95.

Dolezel J and Bartos J. 2005. Plant DNA flow cytometry and estimation of Nuclear Genome Size. Annals of Botany. vol 95:99-100.

Hanif Z dan Ashari H. 2013. Sebaran Stroberi (Fragaria $x$ ananassa) di Indonesia. Kota Batu: Balai penelitian tanaman jeruk dan buah subtropika.

Hummer KE, Bassil N, Njuguna W. 2011. Fragaria. USA: Springer.

Mukti AT. 2005. Perbedaan Keberhasilan Tingkat Polipliodisasi Ikan Mas (Cyprinus carpio Linn.) melalui Kejutan Panas. Berkala Penelitian Hayati. vol (10):133-138.
Nathewet P, Yanagi T, Hummer KE, Iwatsubo Y, Sone K. 2009. Karyotype Analysis in Wild Diploid, Tetraploid and Hexaploid Strawberries. Cytologia. vol 74(3): 355.

Ochatt SJ. 2006. Flow Cytometry (Ploidy determination, Cell Cycle Analysis, DNA content per nucleus). France: Medicago truncatula handbook.

Ochatt SJ. 2008. Flow Cytometry in Plant Breeding. International Society for Advancement of Cytometry (ISAC). vol 73A:581-598.

Suryo. 2007. Sitogenetika. Cetakan ke-2. Yogyakarta: Universitas Gadjah Mada Press.

Sutikno. 1997. Jumlah Kromosom pada berbagai Kultivar Salak (Salacca edulis Reinw.) di Kabupaten Sleman Daerah Istimewa Yogyakarta. Yogyakarta: Laporan Penelitian Universitas Gadjah Mada-Depdikbud.

Wang B, Zuoya D, Wei L, Jin P, Changbao L, Song G, Daming Z. 2009. Polyploid Evoluiton in Oryza officinalis Complex of the Genus Oryza. BMC Evolutionary Biology. vol (9):25. 